\title{
ACUTE ORAL AND INHALATION THALLUM POISONINGS AND THEIR REMOTE CONSEQUENCES (Literature review and data from our own research)
}

\author{
G. Balan', A. Bohomol², P. Zhminko1, N. Bubalo³, V. Bubalo1, \\ A. Kudriavtseva', V. Babich', T. Mymrenko' \\ ${ }^{1}$ L.I. Medved's Research Centre of Preventive Toxicology, Food and Chemical Safety, Ministry of \\ Health, Ukraine (State Enterprise), Kyiv, Ukraine \\ ${ }^{2}$ Kyiv City Clinical Hospital of Emergency Medical Care, Kyiv, Ukraine \\ ${ }^{3} \mathrm{SSI}$ "Research and Practical Center of Preventive and Clinical Medicine", of State Administration of \\ Affairs of the President of Ukraine, Kyiv, Ukraine
}

\begin{abstract}
Aim of the Research. To generalize modern literature data on the toxicity of thallium compounds $\left(\mathrm{Tl}^{+}\right)$, the mechanisms of their toxic effects and to analyze the prevalence of acute $T++$ poisonings in recent years abroad and in Ukraine. Compare the features of the clinical manifestations and outcome of $\mathrm{Tl}^{+}$intoxications with the dose received and the content of $\mathrm{Tl}^{+}$in biological media.

Methods and Materials. A scientific analysis of literature data and our own observations on the prevalence, characteristics of clinical manifestations and outcomes of acute poisoning with thallium compounds was carried out.

Results. An increase in the prevalence of single and group cases of acute $\mathrm{Tl}^{+}$poisoning in recent years both abroad and in Ukraine has been revealed. It was established that among the clinical manifestations of $\mathrm{Tl}^{+}$poisoning, neurological disorders, gastrointestinal and dermatological symptoms predominate, the severity of which in most cases depends on the content of $\mathrm{Tl}^{+}$in biological media, mainly in urine and nails.

Conclusions. Diagnosis of acute $\mathrm{Tl}^{+}$poisoning in most cases is delayed or posthumous. When combining previous gastrointestinal and dermatological disorders with painful paresthesias and ascending sensory and motor disorders of innervation in the lower and upper extremities, it is necessary to conduct a chemical-analytical determination of Tl in the patient's biological media to exclude or confirm intoxication.
\end{abstract}

Key Words: thallium, mechanisms of toxic effects, acute poisoning, diagnostics.

Introduction. Thallium ( $\mathrm{Tl})$ is a silver-white metal. Its main compounds are thallium sulfate, thallium acetate, thallium iodide, thallium bromide, thallium oxide, thallium hydroxide, thallium fluoride, thallium carbonate, thallium nitrate.

Thallium and its compounds $\left(\mathrm{Tl}^{+}\right)$are widely used in various industries. Thallium is used in some alloys, for example, acid-resistant, in the form of an amalgam in the manufacture of thermometers. The addition of small amounts of thallium can significantly reduce the consumption of expensive materials. Thallium is widely used in the production of new semiconductor materials with changing properties, for photo-resistance, photocells with great sensitivity. Thallium metal is added to alloys with other substances for the manufacture of phototriodes, for doping germanium, silicon, etc. $\mathrm{Tl}^{+}$compounds are widely used in the nuclear industry as activators of luminescent alkali-halide crystals, in various types of scintillation counters. In electrical engineering, thallium is used for the calibration of spectral instruments, for the produc- tion of electrodeless discharge lamps, and for the manufacture of thermometers. The instrumentation also uses the radioactive isotope $\mathrm{Tl}-$ T1204 used as a permanent source of beta radiation.

$\mathrm{Tl}^{+}$salts are widely used for growing crystals, which find a wide variety of applications: in optics, $\mathrm{TlBr}-\mathrm{TlJ}$ crystals are used as prisms and lenses of infrared spectroscopy, infrared achromatic lenses, and as lens elements for microscope lenses. Tl alloys have high antifriction properties and high corrosion resistance. In geology, thallium is a part of a special reagent - «Clerici solution» - liquid organic compound with a density of $4.2 \mathrm{~g} / \mathrm{cm}^{3}$, yellow, easily decomposed in the light (to determine the presence of non-ferrous metals) $[1,2,3]$.

Until the 80s, thallium salts were widely used in agriculture as rodenticides and insecticides, in the treatment of grain (seed stock), as well as in dermatology as a part of means for hair removal and treatment of dermatomycoses.

In Ukraine, $\mathrm{Tl}$ compounds were banned as rodenticides, insecticides and depilators back 


\section{ORIGINAL RESEARCH \\ CLINICAL TOXICOLOGY}

in the 80s, however, in recent years, the sale of thallium sulfate in bulk and retail from China has been actively advertised on the Internet, which has led to an increase in criminal episodes, both oral and inhaled acute poisoning with this compound.

Thallium compounds are colorless, tasteless and odorless, very toxic (hazard class 1) and have a sufficiently high-water solubility, which is why they are often used for criminal purposes. With increased availability, thallium compounds are more often used for suicidal purposes, and poisoning occurs with accidental use. The ability of $\mathrm{Tl}^{+}$salts to penetrate the respiratory system, intact skin and mucous membranes contributes to the occurrence of industrial poisoning when working with the specified substance without observing safety requirements and hygiene regulations [1-4]. In addition, the potential environmental risk of thallium intoxication in geochemical provinces with an increased content of its compounds in soil or water has been described $[4,9]$. Thus, the potential health risk of thallium during flowering of cabbage and lettuce in some provinces of China has been described [6].

It should be noted the clinical picture of acute or subacute poisoning with $\mathrm{Tl}^{+}$compounds specific characteristic symptoms (alopecia, etc.) appear late, and therefore patients often die without an accurate diagnosis of thallium poisoning (most often they are admitted to the hospital with suspected encephalomyelitis of viral or bacterial nature), less often - with a suspicion of foodborne toxicosis) $[1,2,3,4,10]$, diabetic neuropathy, Guillain-Barre syndrome and others $[1,2,3,4,9]$.

Unfortunately, the untimely establishment of an accurate diagnosis has led to the development of a number of deaths in patients in our country in recent years. And later, the diagnosis of $\mathrm{Tl}^{+}$ poisoning and the delayed use of antidotes in surviving patients was accompanied by the formation of gross neurological disorders, followed by severe disability. The diagnostics of unusual poisoning with $\mathrm{Tl}^{+}$sulfate during inhalation was particularly difficult. In the literature, there is practically no description of the features of the clinic of inhalation poisoning with $\mathrm{Tl}^{+}$compounds. This necessitated updating information on $\mathrm{Tl}^{+}$toxicity and analysis of modern scientific and methodological approaches to the diagnosis of acute and subacute oral and especially inhala- tion poisoning with compounds of this metal in order to increase the level of information among toxicologists and medical practitioners of other specialties.

Aim. To generalize modern literature data on the toxicity of thallium compounds $(\mathrm{Tl}+)$, the mechanisms of their toxic effects and to analyze the prevalence of acute $\mathrm{Tl}+$ poisonings in recent years abroad and in Ukraine. Compare the features of the clinical manifestations and outcome of $\mathrm{Tl}+$ intoxications with the dose received and the content of $\mathrm{Tl}+$ in biological media.

Methods and Materials. A scientific analysis of literature data and our own observations on the prevalence, characteristics of clinical manifestations and outcomes of acute poisoning with thallium compounds was carried out.

Results. Routes of entry and elimination of thallium from the body.Soluble $\mathrm{Tl}^{+}$salts are absorbed both by ingestion (within 2-3 hours), and by parenteral administration, through intact skin, and also by inhalation $[1,2,3]$. At the same time, well-soluble $\mathrm{Tl}^{+}$salts (sulfate, acetate, carbonate) are more rapidly absorbed in the intestine than less soluble (sulfite and iodide). After oral administration of thallium sulfate, it can be detected in feces and urine within one hour. After $\mathrm{Tl}^{+}$enters the body by any means, it is rapidly distributed by hematogenous route over almost all tissues. [1, $2,9]$. In the early stages, higher $\mathrm{Tl}^{+}$concentrations are found in the liver, kidneys, brain, peripheral nerves, heart, and testicles [11]. In rat brain tissue, from the 5th to the 20th day after exposure to $\mathrm{Tl}^{+}$, its content in the cortex is lower than in the hypothalamus [11, 12].

In humans and animals, $\mathrm{Tl}^{+}$is not metabolized and excreted mainly by the kidneys with urine (up to $70 \%$ ) and feces, as well as with saliva, sweat, tears, and breast milk [12, 13]. The half-life of $\mathrm{Tl}^{+}$from the human body depends on the dose, age, and kidney function and ranges from 4 to 30 days, and an increased concentration can be observed up to several months [1, 11, 12]. When exposed to large doses, elevated concentrations of thallium in the blood and urine are detected within a few months, since it accumulates in the bones and is slowly excreted, especially in cases of impaired renal function $[1,11]$.

A lethal outcome is noted when $10-15 \mathrm{mg}$ of soluble thallium salt per $1 \mathrm{~kg}$ of body weight is 
consumed, but lethal outcomes are also described at lower doses [1, 4]. A dose of $1 \mathrm{~g}$ of thallium salts is absolutely lethal. The normal content of thallium in the blood should not exceed $2 \mu \mathrm{g} / 1$, in the urine $-200 \mu \mathrm{g} / \mathrm{l}$. A concentration in the blood of more than $100 \mu \mathrm{g} / \mathrm{l}$, in the urine - more than $200 \mu \mathrm{g} / 1$ is considered toxic.

The main mechanisms of the toxic effect of thallium compounds. By the general nature of the action, $\mathrm{Tl}^{+}$refers to poisons that affect the central and peripheral nervous systems, liver, gastrointestinal tract and kidneys. In addition, thallium and its salts have a mutagenic, carcinogenic, teratogenic and embryotoxic effect $[1,4,13]$. The exact mechanisms of $\mathrm{Tl}^{+}$toxicity have not yet been disclosed [1, 3, 4]. It is known that thallium compounds bind $\mathrm{SH}-$ groups on mitochondrial membranes and disrupt the $\mathrm{Na}^{+}-\mathrm{K}^{+}$pump, interactions with $\mathrm{Na}^{+}$ $-\mathrm{K}^{+}$-ATPase, the affinity of which is 10 times greater than that of potassium [1, 3, 4, 22]. Inactivation of sulfhydryl groups that regulate the permeability of mitochondrial membranes leads to an excessive flow of water into the mitochondria and their swelling. It was shown that the ATP content in the liver and kidneys of mice after injection of thallium sulfate at a dose of $25 \mathrm{mg} / \mathrm{kg}$ increased almost 2 times, but after 20 hours it decreased to normal. Moreover, the activity of the enzyme $\mathrm{Na}^{+}-\mathrm{K}^{+}$ -ATPase of the liver and kidneys initially decreased and then significantly increased, remaining at an elevated level for 240 hours, which reflects the damaging effect of $\mathrm{Tl}^{+}$on the liver and kidney parenchyma [18].

There is an ionic similarity in the compounds of thallium and potassium, they can be in a state of biological interaction, and $\mathrm{Tl}^{+}$is many times more active than potassium, therefore, it replaces potassium and competes with it for a place in biological membranes, many enzymes [1, 3, 4, 12]. Potassium infusion increases the renal clearance of $\mathrm{Tl}^{+}$and its removal from tissues, but this opinion is not unambiguous. An increase in the potassium content in the rat diet leads to an increase in $\mathrm{LD}_{50} \mathrm{Tl}^{+}[1]$.

The toxic effects of $\mathrm{Tl}^{+}$in both animals and humans are predominantly characterized by its neurotoxic effect that occurs already on the first day, in particular in the form of a change in behavior: drowsiness or agitation up to delirium. Lesions of the central and peripheral nervous systems are observed for 2-3 days, which intensify after a few days and are characterized by damage to the cranial nerves, cortex, subcortical structures (accumulating in the hippocampus, cerebellum, striatum, hypothalamus and peripheral nerves) [1-4]. At high doses of $\mathrm{Tl}^{+}$, these changes with simultaneous damage to the liver, heart, and kidneys in a person lead to death in 4-7 days, most often without an accurate diagnosis.

The mechanisms of neurotoxicity of $\mathrm{Tl}^{+}$are still unclear [1, 19]. In recent years, evidence has emerged that the neurotoxic effects of $\mathrm{Tl}^{+}$ are associated with mitochondrial dysfunction, activation of lipid peroxidation, and inhibition of $\mathrm{Na}^{+} / \mathrm{K}^{+}$-ATPase activity $[1,4,14,15,17-$ $22,26]$. These effects were also detected on synaptosomal mitochondrial crude P2 fractions of rat brain under the influence of $\mathrm{Tl}^{+}(5-$ $250 \mu \mathrm{M}$ ) for 30 minutes, and the optimal concentration for their detection is $5 \mu \mathrm{M} \mathrm{Tl}^{+}$[19]. The authors note that the basis of the neurotoxic effect of $\mathrm{Tl}^{+}$is mitochondrial dysfunction with a decrease in mitochondrial recovery capacity and the formation of energy deficiency, oxidative stress and a decrease in the activity of $\mathrm{Na}^{+} / \mathrm{K}^{+}$-ATPase. To a large extent, neurotoxicity of thallium is caused by the appearance of excessive excitability of nerve cells when it acts on the brain of rats [20]. Using NMDA receptor antagonists (N-Methyl-D-Aspartate Receptor), it was possible to identify the glutamatergic component in $\mathrm{Tl}^{+}-$induced toxicity, especially when exposed to high doses $(32 \mathrm{mg} / \mathrm{kg})$ [26]. The authors showed the modulating effect of glutamate (NMDA receptors) on the distribution of $\mathrm{Tl}^{+}$in different brain structures, and also revealed that the preliminary effect of an NMDA receptor antagonist - MK-801 helps to reduce $\mathrm{Tl}^{+}$hyperlocation in brain structures and the severity of thallium-induced oxidative stress (decrease in ATP production) Strong depletion of the main antioxidant - glutathione in the brain structures was also found, especially 7 days after exposure to $\mathrm{Tl}^{+}$[26].

In a number of studies, it was found that exposure to $\mathrm{Tl}^{+}$stimulates massive swelling with subsequent destruction of intracellular and mitochondrial membranes due to an increase in the concentration of calcium ions with a simultaneous sharp decrease in potassium in the cells, as well as associated with ATP deficiency, inhibition of SH-groups, activation of lipid peroxidation, and violation of oxida- 


\section{ORIGINAL RESEARCH \\ CLINICAL TOXICOLOGY}

tive phosphorylation with the formation of energy deficiency [1, 21-24]. Loss of ATP and energy deficiency in turn lead to disruption of the operation of ion pumps, to depolarization of cell and mitochondrial membranes, depending on the voltage of NMDA receptors, which makes neurons more vulnerable to basal levels of glutamate and is one of the causes of cell death [26]. $\mathrm{Ca}_{2+}$ overload caused by excessive activation of NMDA receptors (a subtype of glutamate receptors) also leads to cellular disorders, including changes in signaling pathways, in the formation of mitochondrial dysfunction, metabolic and morphological disorders and activation of apoptosis [26]. Mitochondrial dysfunction and excessive intake of $\mathrm{CA}_{2+}$ into cells cause a decrease in protein synthesis and disaggregation of polyribosomes of the liver and other organs [19-24]. It is known that ribosome biogenesis is a complex process and is important for cell growth and proliferation processes. $\mathrm{Tl}^{+}$reduces ribosomal subunits in a dose-dependent manner, alters pRNK processing, localization and the number of important nuclear proteins, and blocks the process of exporting preribosomes. In turn, disturbances in the synthesis of ribosomes cause stress in the nuclear structures, which leads to a stop of the cell cycle and apoptosis.

In the mechanism of $\mathrm{Tl}^{+}$toxicity, an important role is also given to metabolic disorders of riboflavin, with which it forms insoluble complexes with the formation of subsequent riboflavin deficiency [1-4]. In addition, $\mathrm{Tl}^{+}$ causes the development of normochromic anemia. A decrease in the number of red blood cells with tallotoxicosis is accompanied by a decrease in their acid resistance and an increase in their decay. At the same time, they increase the level of 2,3-diphosphoglyceric acid, which reduces the affinity of hemoglobin for oxygen, which contributes to the formation of tissue hypoxia. $\mathrm{Tl}^{+}$along with specific clinical manifestations leads to a pronounced cytotoxic effect [22]: when analyzing the blood of patients, in addition to normochromic anemia, a cytolytic syndrome of liver damage with an increased content of ALT, AST and bilirubin, as well as an increase in the blood of creatinine, urea of cortisol, which indicates a violation functions of the liver, kidneys and adrenal glands [1-4, 36-44]. An increased ability of blood mononuclear cells to generate nitric oxide in blood serum was detected, during incubation of diluted blood an increased content of tumor necrosis factor $\alpha$ was found, and an increased expression of heat shock protein of $70 \mathrm{Da}$, especially its inducible form, was found in blood mononuclear cells [22-24]. The latter circumstance is a consequence of denaturation changes in cell proteins and activation of free radical reactions [19, 22, 24].

The mechanisms of the toxic effect of $\mathrm{Tl}^{+}$ on skin cells are also quite complex. Histological studies in patients with $\mathrm{Tl}^{+}$intoxication reveal parakeratosis, focal epidermal necrosis. It has been shown that $\mathrm{Tl}^{+}$can alter the usual epidermal keratinization program, inhibit cell proliferation, especially follicular melanocytes, which contributes to its high affinity for melanin. Thallium disrupts keratinocyte differentiation, inhibits mitochondrial activity in the hair (especially in the hair follicle cells), linking SH-groups of enzymes $[1-4]$. The key symptoms that make $\mathrm{Tl}^{+}$poisoning suspected are alopecia (mainly in the parietooccipital region), loss of eyelashes and medial-lateral areas of the eyebrows [1-4, 2733]. There is a fusiform swelling close to the root area of the hair, a significant amount of black pigment in the roots, the disappearance of the root sheath.

Since the effect of $\mathrm{Tl}^{+}$on humans through natural, professional, intentional, and random sources is a growing problem for human health, the mechanisms of formation of its neurotoxic and other adverse effects require further study to develop new diagnostic methods and rational therapy.

The study of acute $\mathrm{Tl}^{+}$toxicity showed that the frequency and severity of the pathophysiological and pathomorphological manifestations of the toxic effects of $\mathrm{Tl}^{+}$in experimental animals depend on the dose, the route of entry into the body, on the chemical properties of $\mathrm{Tl}$ salts, especially their degree of water solubility and to a lesser extent on gender and age $[1,4$, $40,47]$. In acute oral exposure to $\mathrm{Tl}^{+}$nitrate and sulfate in rats at doses of $10-20 \mathrm{mg} / \mathrm{kg}$, LOAEL was established at $15 \mathrm{mg} / \mathrm{kg} \mathrm{Tl}^{+}$, while the main demonstrations of the toxic effect are shortness of breath, tousled hair, salivation and lacrimation, agitation, at autopsy increase in the absolute weight of the kidneys and adrenal glands, micro bleeding in the brain, liver and kidneys, death within 1 day. After a single intraperitoneal injection of a 
solution of $\mathrm{Tl}^{+}$acetate in newborn rats, neuromyopathy was morphologically revealed after 8 and 50 days [47]. On the 8th day, the number of large and medium-sized fibers in the fibular nerve slightly decreased and signs of degeneration of the myelin sheaths along the axon appeared. In both the nervous and muscle tissue, interstitial edema was detected. In addition, signs of focal necrosis and minor hemorrhages were found in the muscle, and the muscle fibers themselves had myopathic changes with abnormal nucleoli and transverse striation that disappeared in many places. There were signs of fibrosis in some foci of necrosis. A number of authors [1, 4, 47] note degenerative changes in experimental animals under the influence of $\mathrm{Tl}^{+}$not only in nerve cells of the brain and in peripheral nerves, but also in hepatocytes, in the renal tubules, as well as in the cranial nerves, especially the visual and facial.

Clinic of acute oral and inhalation poisoning with thallium compounds in humans in the acute and distant period and modern principles of their diagnosis. Over the past 25 years, in many countries of the world, including Ukraine, the frequency of $\mathrm{Tl}^{+}$poisoning has increased with random, suicidal use, and especially group poisoning in criminal incidents [23-46]. G.A. Livanov et al. [46] describe acute oral group severe $\mathrm{Tl}^{+}$poisoning in Russia in the city of Yaroslavl (14 people), Moscow (8 people), St. Petersburg (5 people) of a criminal nature.Poisoning at $\mathrm{Tl}^{+}$concentrations in the urine of $1800-2440 \mu \mathrm{g} / 1$ in the victims $2-3$ weeks after the onset of intoxication symptoms, the authors regarded as severe, at concentrations of 324-1690 $\mu \mathrm{g} / 1$ - as moderate and below $300 \mu \mathrm{g} / 1-$ as mild form (permissible average level of $\mathrm{Tl}^{+}$in urine as determined by atomic absorption spectrophotometry is 1.7 $\mu \mathrm{g} / 1$ ). Di Candia D. et al. [24] describe 8 cases of thallium sulfate poisoning in one family, while the $\mathrm{Tl}^{+}$concentrations in the victims' blood after a week were more than $1000 \mu \mathrm{g} / 1$. L.B. Zavaliy et al. [28] describe 44 cases of oral acute $\mathrm{Tl}^{+}$poisoning at a plant in Taganrog (probably of a criminal nature). All patients were examined at the Moscow Research Institute of Emergency Medicine and 69 days after the onset of poisoning symptoms in 7 patients, the Tl level in the blood averaged $13.7 \mu \mathrm{g} / 1$, in the urine $-95.64 \mu \mathrm{g} / 1$ - their clinical condition was regarded as moderate severity. In the remaining patients, the $\mathrm{Tl}$ level in the blood averaged $2.1 \mu \mathrm{g} / 1$, in the urine $17.39 \mu \mathrm{g} / \mathrm{l}$ and their poisoning was regarded as mild. In two patients, the $\mathrm{Tl}^{+}$content in the blood was 24.05 and $19.4 \mu \mathrm{g} / 1$, in the urine 356.1 and $102.9 \mu \mathrm{g} / 1$, respectively. It is noteworthy that patients were admitted to the clinic 69 days after the onset of intoxication symptoms, while they noted pain and weakness in the arms and legs, general weakness, fatigue, memory impairment, impaired gait, numbness in the fingers and toes. During hospitalization, coordinating $(n=22)$, sensitive $(n=16)$, motor disorders $(n=22)$, impaired $\mathrm{CN}$ function $(n=12)$, hand tremor $(n=9)$, and neurological disorders in such a long period were revealed correlated with thallium level in urine.

In works where patients were observed on the first day after $\mathrm{Tl}^{+}$poisoning, the majority of authors noted the appearance of abdominal pain, up to intestinal colic and the appearance of green urine in the first hours of intoxication, as well as anorexia, gastroenteritis with diarrhea, less often with constipation, fever [ $1-4$, 27-46]. After 8-40 hours, disorders of the nervous system occur - excitement or drowsiness, insomnia, anxiety, severe weakness, muscle pain, very painful paresthesia in the hands and feet, especially in the sole, ataxia, trembling throughout the body, tremor of the fingers, cramps, in severe cases - coma. Mental disorders can occur - depression, hallucinations, agitation, up to acute confusional state [1-4, $10-13,16,27-44]$. When exposed to large doses of $\mathrm{Tl}^{+}$after 5-6 days, respiratory and circulatory disorders join in, which increase and end in death 7-10 days after poisoning, but often 3-5 days, usually without an accurate diagnosis. In surviving patients, neurological disorders in the form of intense headache, ataxia, tremors, excruciating neuropathic pains and paresthesia in the hands and feet, in the muscles of the legs with the formation of myoneuropathy increase. At the same time, neuropathies of the cranial nerves are formed with the formation of ptosis, nystagmus, paresis of the facial nerve, strabismus, often paresis of the optic nerve with the development of retrobulbar neuritis with loss of vision. In more severe cases, encephalo-myelo-radiculo-neuropathy is formed with severe ataxia, with paresis of the upper and lower extremities, often with impaired vision and speech [1-4, 27-46]. Most 


\section{ORIGINAL RESEARCH \\ CLINICAL TOXICOLOGY}

patients develop toxic hepatitis with cytolytic syndrome with increased levels of ALT, AST, GGT, toxic nephropathy with hyperproteinuria, increased levels of blood creatinine and urea [27-46].

Usually, diffuse alopecia develops after 814 days, mainly in the parietal-occipital area, less often in the temporal areas.Alopecia is usually preceded by brown pigmentation of the scalp, the accumulation of black pigment at the root of the hair. At the same time, there is eyebrow loss, more in the medial and lateral third, and eyelash loss, as well as a decrease in hairline on the legs, in men - on the chest. The appearance of transverse white Muehrcke's lines on the nails is formed. At the same time, skin manifestations in the form of peeling, cracks in the corners of the mouth, severe hyperkeratosis of the palms and soles, stomatitis, glossitis, pustular rashes on the face, conjunctivitis appear. Skin manifestations are associated with the formation of riboflavin deficiency during $\mathrm{Tl}^{+}$poisoning, with impaired protein synthesis, and suppression of immune responses [1-4].If skin manifestations and alopecia regress after 1.5-2 months, neurological disorders last for a long time - for several months and years, often leading to severe disability due to the development of tetraparesis, ataxia, visual and speech impairment, as well as mental disorders. If the clinic of acute oral poisoning with $\mathrm{Tl}^{+}$salts has been described quite well, then there are practically no descriptions of the clinical manifestations of acute inhalation poisoning with $\mathrm{Tl}^{+}$.

Based on published data, we tried to determine the dependence of the severity of clinical manifestations and their outcome in patients who underwent acute oral $\mathrm{Tl}^{+}$poisoning, on the value of the accepted dose of $\mathrm{Tl}^{+}$and its concentration in biological media (blood serum and urine, Table 1).

Table 1 shows that there is no clear correlation between the severity of clinical manifestations and the oral dose of $\mathrm{Tl}^{+}$, in addition, the dose itself is always in doubt. A clear direct relationship between the lethal outcome and the level of $\mathrm{Tl}^{+}$in serum is not determined: the lethal outcome was recorded at a concentration of $\mathrm{Tl}^{+} 4220 \mu \mathrm{g} / 1$ and at $8790 \mu \mathrm{g} / 1$. It should be noted that a patient with a fatal outcome with a $\mathrm{Tl}^{+} 4220 \mu \mathrm{g} / 1$ level was at the age of 80, which apparently contributed to the fatal outcome [33]. In addition, he had a very high concentration of $\mathrm{Tl}^{+}-21600 \mu \mathrm{g} / \mathrm{l}$ in his urine.
Surviving patients showed progression of neurological and mental disorders up to a year [34-37] with stabilization of clinical manifestations in $1.0-1.5$ years.

In Ukraine, in recent years, the development of acute oral $\mathrm{Tl}^{+}$poisoning has become more common, including in severe form, as well as an unusual group case of acute inhalation poisoning with thallium sulfate vapors has been recorded.

The most famous case of strictly group oral poisoning of $\mathrm{Tl}^{+}$was a criminal incident in March 1987 in one of Kyiv schools, where the dishwasher Ivanyutina Tamara decided to poison the cook due to personal hostility and added Clerici liquid (the most highly toxic compound of thallium) to the food left over from dinner. This tragic story was widely covered in the open press and on television [5558], on one of the TV channels the documentary series "Otruyna Shkola" was shown [58]. Unfortunately, 13 people later came to the dining room (schoolchildren and several teachers), who were fed a poisoned lunch. After a couple of hours, all 13 diners started vomiting, had intense abdominal pain, diarrhea, chills, fever, muscle pain in the limbs. Patients with suspected food intoxication were hospitalized in the intensive care unit. Symptoms during hospitalization included agitation, facial flushing, fever, nausea, vomiting, intense abdominal pain, diarrhea, generalized muscle pain, agonizinglypainful paresthesia in the hands and feet, cramps. Two schoolchildren and two teachers died on the first day of increasing pulmonary heart failure, the remaining 9 people continued treatment for foodborne toxic infection in intensive care. On day 8-10, intense hair loss began, $\mathrm{Tl}^{+}$poisoning was suspected, the $\mathrm{Tl}^{+}$content in the blood serum in 9 patients ranged from 4660 to $22840 \mu \mathrm{g} / 1$. $\mathrm{Tl}^{+}$poisoning was confirmed during the exhumation of a school nurse who died two weeks before the incident, allegedly from cardiovascular disease. The investigation found that for 11 years Ivanyutina (was sentenced to death) and her sister poisoned 40 people with $\mathrm{Tl}^{+}, 13$ of them died [55-58].

After poisoning at school 9 survivors underwent long-term treatment. Of these, 5 adult employees for 6 years underwent annual examination and treatment at the ECOGINTOXA clinic (now the "L.I. Medved's Research Center of Preventive 
Comparison of the accepted dose of $\mathrm{Tl}+$ and its concentrations in the blood and urine with the severity of the clinical manifestations of acute $\mathrm{Tl}+$ poisoning in patients and the outcome of intoxication

\begin{tabular}{|c|c|c|c|c|}
\hline Authors & $\begin{array}{c}\text { Dose of } \mathrm{Tl}^{+} \text {and } \\
\text { content in biological } \\
\text { media }\end{array}$ & Clinical manifestations & Outcome & Age / gender \\
\hline $\begin{array}{l}\text { Davis } \\
\text { L.E. et al. } \\
\text { [31] }\end{array}$ & $\begin{array}{l}\text { Dose } 5-10 \mathrm{~g} \text { of } \\
\text { thallium sulfate }\end{array}$ & $\begin{array}{l}\text { Drooling, runny nose, painful } \\
\text { paresthesia and pain in hands } \\
\text { and feet, acute respiratory fail- } \\
\text { ure. Morphologically: focal } \\
\text { necrosis in the structures of the } \\
\text { central nervous system and } \\
\text { peripheral nerves, demyelination } \\
\text { of peripheral nerves. }\end{array}$ & $\begin{array}{l}\text { Lethal } \\
\text { after } 1 \text { day }\end{array}$ & $\begin{array}{c}19 \text { years old, } \\
\text { male }\end{array}$ \\
\hline $\begin{array}{l}\text { Sharma } \\
\text { A.N. } \\
\text { et al. [32] }\end{array}$ & $\begin{array}{l}\text { Dose unknown, } \\
\mathrm{Tl}^{+} \text {in the blood of } \\
8700 \mu \mathrm{g} / 1, \\
\text { in the urine - } \\
50,000 \mu \mathrm{g} / 1, \\
\text { in the cerebrospinal } \\
\text { fluid }-20,000 \mu \mathrm{g} / 1\end{array}$ & $\begin{array}{l}\text { Confused consciousness, agita- } \\
\text { tion, neuropathic pain in the } \\
\text { arms and legs, coma, acute respi- } \\
\text { ratory failure }\end{array}$ & $\begin{array}{l}\text { Lethal after } \\
3 \text { days }\end{array}$ & $\begin{array}{l}48 \text { years old, } \\
\text { male }\end{array}$ \\
\hline $\begin{array}{l}\text { Roby } \\
\text { D.S. at al } \\
{[33]}\end{array}$ & $\begin{array}{l}\text { Dose unknown, } \\
\mathrm{Tl}^{+} \text {in blood } 4220 \\
\mu \mathrm{g} / 1, \text { in urine }- \\
21600 \mu \mathrm{g} / 1\end{array}$ & $\begin{array}{l}\text { Acute respiratory distress syn- } \\
\text { drome }\end{array}$ & Lethal on the 1st day & $\begin{array}{l}80 \text { years old, } \\
\text { male }\end{array}$ \\
\hline $\begin{array}{l}\text { Kuo H.C. } \\
\text { et al. [34] }\end{array}$ & $\begin{array}{l}\text { Dose unknown, } \\
\mathrm{Tl}^{+} \text {in blood } 2800 \\
\mu \mathrm{g} / 1, \text { in urine }- \\
4600 \mu \mathrm{g} / 1\end{array}$ & $\begin{array}{l}\text { Excitement, intense pain and } \\
\text { paresthesia in the hands and feet, } \\
\text { diarrhea, alopecia }\end{array}$ & $\begin{array}{l}\text { Increase in damage } \\
\text { to the nervous system } \\
\text { and ataxia - up to } \\
\text { a year, stabilization } \\
\text { of clinical manifesta- } \\
\text { tions after } 2 \text { years }\end{array}$ & $\begin{array}{l}56 \text { years old, } \\
\text { male }\end{array}$ \\
\hline $\begin{array}{l}\text { Tsai Y.T. } \\
\text { et al. [35] }\end{array}$ & $\begin{array}{l}\text { Dose } 1.5-2.0 \mathrm{~g}, \mathrm{Tl}^{+} \\
\text {in the blood } \\
4400 \mu \mathrm{g} / 1, \text { in the } \\
\text { urine }-3860 \mu \mathrm{g} / 1\end{array}$ & $\begin{array}{l}\text { Confused consciousness, halluci- } \\
\text { nations, feelings of anxiety, } \\
\text { depression, memory loss, facial } \\
\text { flushing, diarrhea, tachycardia, } \\
\text { alopecia, encephalopathy, } \\
\text { peripheral neuropathy }\end{array}$ & $\begin{array}{c}\text { Progression of } \\
\text { encephalopathy and } \\
\text { polyneuropathy up } \\
\text { to } 6 \text { months, } \\
\text { increased mental and } \\
\text { cognitive impairment } \\
\text { after } 9 \text { months, stabi- } \\
\text { lization of clinical } \\
\text { manifestations after } \\
1.5 \text { years }\end{array}$ & $\begin{array}{l}48 \text { years old, } \\
\text { male } \\
52 \text { years old, } \\
\text { female }\end{array}$ \\
\hline $\begin{array}{l}\text { Lu C.I. et } \\
\text { al. [36] }\end{array}$ & $\begin{array}{l}\text { The dose is } 1.0-1.5 \\
\mathrm{~g}, \mathrm{Tl}+\text { in the blood } \\
\text { is } 950,2050 \mu \mathrm{g} / 1, \\
\text { in the urine }- \\
11325,14520 \mu \mathrm{g} / 1 .\end{array}$ & $\begin{array}{l}\text { Runny nose, nausea, generalized } \\
\text { muscle pain, paresthesia and } \\
\text { dysesthesia in the hands and feet, } \\
\text { urinary retention, hyporeflexia, } \\
\text { weakness, acneiform dermatitis, } \\
\text { alopecia (1-3 weeks). Skin nerve } \\
\text { biopsy: axonal degeneration, } \\
\text { demyelination }\end{array}$ & $\begin{array}{l}\text { Progression of neuro- } \\
\text { logical disorders up to } \\
\text { a year, then stabiliza- } \\
\text { tion of clinical mani- } \\
\text { festations }\end{array}$ & $\begin{array}{l}49 \text { years old, } \\
\text { female, } \\
52 \text { years old, } \\
\text { male }\end{array}$ \\
\hline
\end{tabular}




\section{ORIGINAL RESEARCH \\ CLINICAL TOXICOLOGY}

Toxicology, Food and Chemical Safety", hereinafter referred to as the "Research Center"). If in the first two years after poisoning there was an increase in neurological, cognitive impairment and ataxia, then in subsequent years, 1 out of 5 showed stabilization of neuromuscular disorders, and 4 had a slow regression of encephalo-polyneuropathy.

In recent years, we have observed 3 cases of severe peroral $\mathrm{Tl}^{+}$poisonings, of which 2 are of a criminal nature and 1 is due to the accidental use of a solution of thallium sulfate prepared supposedly for deratization. In all three cases, the disease began with abdominal pain, nausea, vomiting, diarrhea, fever, intense muscle pain in the limbs, painful paresthesia in the hands and feet, seizures in the limbs. After 5-8 days, all three victims developed alopecia, mainly in the parieto-occipital area, pyoderma in the face, cracks in the corners of the mouth, hyperkeratosis in the hands and feet, weakness in the limbs.After 8-10 days, dysarthria, ataxia, flaccid paresis of the upper and especially lower extremities appeared, decreased activity of tendon reflexes of the hands, disappearance of knee, Achilles and abdominal reflexes. Two of them showed a decrease in visual acuity, speech impairment. In all three cases, pronounced hypotrophy of the muscles of the legs, hips, shoulders and forearms, and dysfunction of the pelvic organs appeared. In two patients, the determination of $\mathrm{Tl}$ in urine was performed 10-14 days after the onset of the disease and amounted to 2840 and $2160 \mu \mathrm{g} / 1$, respectively. In the third patient, $\mathrm{Tl}^{+}$intoxication was suspected only after a month, the $\mathrm{Tl}$ content in the urine during this period was $1425 \mu \mathrm{g} / \mathrm{l}$. In the first two patients, neurological symptoms increased during the 1st year, then stabilized while maintaining encephalomyelo-polyradiculoneuropathy with weakness in the hands and flaccid paresis of the lower extremities, with severe ataxia and the ability to move only in a wheelchair for 3 years of observation. Conducting complex therapy with the inclusion of the antidote Ferracin contributed to a decrease in the $\mathrm{Tl}$ content in the urine to $100-120 \mu \mathrm{g} / 1$. Within a month, however, a regression of neurological disorders was not observed, visual impairment, depression, cognitive impairment progressed, and pelvic organ dysfunctions persisted. After severe alopecia after 4-6 months in all three cases, thick hair grew. In the third patient, neurological symptoms increased to 6-8 months, then after a long rehabilitation, it decreased slightly. At the control after 1 year, there was a sluggish paresis of the lower extremities, ataxia, but the patient began to move slowly with the help of crutches. All three patients had a disability group I. When conducting EMG, signs of pronounced motor-sensory polyneuropathy of an axonal nature were revealed. It should be noted that tallotoxicosis was established in the first two patients after 10-14 days, and antidotal therapy with Ferracin was carried out in a timely manner, a decrease in the level of $\mathrm{Tl}^{+}$in the urine was detected, but there was practically no regression of neurological symptoms. In a third patient, tallotoxicosis was established only a month later, and before that he was treated in various clinics in Kyiv with a diagnosis of polyneuropathy of unknown etiology with the prescription of hormones, antibiotics and plasmapheresis (No. 5). The antidote Ferracin was prescribed to him a month later, when $\mathrm{Tl}^{+}$in the urine was $1425 \mu \mathrm{g} / 1$, after treatment with the inclusion of Ferracin, $\mathrm{Tl}^{+}$ in the urine decreased to $116 \mu \mathrm{g} / 1$, a year later the patient began to move with crutches. If after a month the level of $\mathrm{Tl}^{+}$in his urine was $1425 \mu \mathrm{g} / 1$, then we can assume that in the acute period his level was much higher. In addition, he received specific therapy a month later, nevertheless, the regression of neurological disorders was more noticeable in comparison with the first two cases.

Three cases of the development of acute inhalation poisoning by $\mathrm{Tl}^{+}$vapors in car drivers are of interest. A year ago, their car was put up for repair in the courtyard of a private individual who kept several dogs that interfered with the lives of neighbors. Probably, one of the neighbors decided to kill the dogs and threw poisoned porridge over the fence. Porridge hit the car and because of the open hood - its engine. The owner wiped the car from porridge outside and his twenty-three-year-old son began to work on it. After 1.5-2 days, he developed an intense burning sensation in the throat, along the trachea, behind the sternum, in the diaphragm, difficulty breathing, intense pain in the muscles of the limbs, periarticular tissues, painful paresthesia in the fingers and toes, stomach pains sharp weakness in the legs. Initially, the patient was treated with suspected neuroinfection, after the appearance of alope- 
cia, acute $\mathrm{Tl}^{+}$poisoning was laboratory-confirmed and the victim was transferred to the emergency hospital. With an increase in pulmonary heart disease, the patient died at the end of the summer of 2018 with a diagnosis of acute $\mathrm{Tl}^{+}$poisoning, however, a connection between the development of intoxication and driving was not established. After the death of a young man, his 42-year-old father and 48year-old partner began to work periodically on this car. In November 2018, when the cold came, they began to turn on the air conditioner to heat the inside of the car, after which they began to notice a burning sensation in the throat, along the trachea, behind the sternum, then both had intense muscle pain, paresthesia in the fingers and toes, weakness in the legs, alopecia began to develop. The father of the deceased young man entered the toxicology department of the emergency hospital in Kyiv in the fall of 2018, where he was treated for 1.5 months with a diagnosis of acute poisoning with $\mathrm{Tl}^{+}$salts, stage II-III encephalo-poliradiculoneuropathy syndrome, and stage I-II toxic hepatitis. A week later, with a similar complaint, his partner, who was treated for 20 days with a diagnosis of acute poisoning with thallium salts, stage II polyradiculoneuropathy syndrome, and stage I-II toxic hepatitis, was admitted to the same department. In both patients, when examined at the Research Center, the level of $\mathrm{Tl}^{+}$in the hair was more than 10 times higher than normal, in the urine $320-280 \mu \mathrm{g} / 1$.

After complex detoxification therapy with hemodialysis, a course of antidote therapy with Ferracin, nootropics, analgesics, anticonvulsants, antioxidants, B, PP vitamins, the patients' condition improved, there was a significant regression of neurological disorders, pains behind the sternum, muscle pains, hair loss stopped.

A chemical-toxicological assessment of the $\mathrm{Tl}^{+}$content in the hair and nails of patients, carried out at the Research Center 2.5 months after acute poisoning, revealed a $\mathrm{Tl}^{+}$content in one patient of $800 \mu \mathrm{g} / \mathrm{kg}$ in the hair, $2230 \mu \mathrm{g} / \mathrm{kg}$ in the nails, and skin epithelium $-190 \mu \mathrm{g} / \mathrm{kg}$. Another patient with more pronounced neurological impairment had higher $\mathrm{Tl}^{+}$levels: in his hair $-3980 \mu \mathrm{g} / \mathrm{kg}$, in his nails $-9080 \mu \mathrm{g} / \mathrm{kg}$, in his skin epithelium - $620 \mu \mathrm{g} / \mathrm{kg}$, which indicates a certain dependence of the severity of clinical manifestations on the content of $\mathrm{Tl}^{+}$ in biological media, mainly in urine and nails. It should be noted that 2.5 months after poisoning, the highest levels of $\mathrm{Tl}^{+}$were observed in the hair and especially the nails of patients. After a year, peripheral polyneuropathy, mild ataxia, tremor of fingers of outstretched arms, hyporeflexia, depression persisted.

Unfortunately, only six months after the occurrence of the first of three cases of acute $\mathrm{Tl}^{+}$poisoning at the Research Center, a chemical toxicological assessment of the interior surfaces of the car was carried out, on which all three victims worked. $5 \% \mathrm{HCl}$ sections of artificial leather were extracted from the front seats and floor mats. In 3 samples taken from the seats after six months, fairly high concentrations of $\mathrm{Tl}^{+}$were detected - up to $68,060 \mu \mathrm{g}$ per $30 \mathrm{ml}$ of extract (or $2269 \mu \mathrm{g} / \mathrm{ml}$ ). In samples from floor mats, the $\mathrm{Tl}^{+}$concentrations in the extracts were slightly lower. Given the contamination of the $\mathrm{Tl}^{+}$car interior, which six months ago, presumably, was more pronounced, acute $\mathrm{Tl}^{+}$poisoning probably arose by inhalation, and the clinical manifestations in the last two patients appeared even when it was cold, in early November, when the car windows were closed, and interior was heated. It should be noted that the Research Center conducted a study of the content of $\mathrm{Tl}^{+}$in biological samples of the exhumed corpse of a man who died in 2019 from a neurological pathology of unknown etiology (at the insistence of relatives who suspected poisoning). In the biopsy area of the skin of the exhumed corpse, the $\mathrm{Tl}^{+}$level reached $8000 \mu \mathrm{g} / \mathrm{kg}$, and in the cut nails $-9000 \mu \mathrm{g} / \mathrm{kg}$, which made it possible to establish that the cause of his death was $\mathrm{Tl}^{+}$poisoning.

The described cases of $\mathrm{Tl}^{+}$intoxication indicate that the availability of the acquisition of its compounds on the Internet contributes to the growth of acute poisoning among the population, in addition, it cannot be ruled out that in many cases patients died before an accurate diagnosis was established.

Conclusion. Thus, according to the literature and analysis of our own observations, acute $\mathrm{Tl}^{+}$poisonings are increasingly recorded in all countries, including Ukraine. First of all, they are manifested by neurological, gastrointestinal and dermatological symptoms, and with inhalation exposure, neurological symptoms and alopecia are preceded by irritation of the upper respiratory tract, intense burning 


\section{ORIGINAL RESEARCH \\ CLINICAL TOXICOLOGY}

sensation along the trachea and behind the sternum. We believe that any unexplained peripheral polyneuropathy with painful paresthesia and muscle pain should cause a suspicion of $\mathrm{Tl}^{+}$intoxication. A combination of previous gastrointestinal disorders with an ascending nature of intense pain and sensory disturbances in the lower and upper extremities, the development of para- or tetraparesis even before the onset of alopecia gives reason to suspect $\mathrm{Tl}$ poisoning and conduct timely chemo-toxicological studies of patients'biomedia. It is not possible to trace a clear connection between the severity of the clinical manifestations of $\mathrm{Tl}^{+}$intoxication and the dose received, but in most cases, the severity of neurological disorders depends on the $\mathrm{Tl}^{+}$content in biological media, especially in urine and nails. Considering that the official distribution of thallium salts in Ukraine has been prohibited since the 80 s of the last century, but there are websites on the Internet with announcements of their sale, we consider it appropriate for law enforcement agencies of Ukraine to block them as well as websites selling drugs or similar to prevent criminal incidents with $\mathrm{Tl}^{+}$ poisoning, as well as the accidental or intentional use of its compounds.

The autors declare that there are no conflicts of interest.

1. Toxicological review of thallium and compounds. U. S. Environmental Protection Agency. Washington. D. C. 2009. EPA/635/R-08/001F.www.epa.gov/iris.

2. Yumoto T., Tsukahara K., Naito H., Iida A., Nakao A. A Successfully Treated Case of Criminal Thallium Poisoning. J Clin Diagn Res. 2017 Apr;11(4): OD01-OD02. doi: 10.7860/JCDR/2017/24286.9494.

3. Al Hammouri F., Darwazeh G., Said A., Ghosh R.A. Acute thallium poisoning: series of ten cases. J Med Toxicol. 2011 Dec;7(4):306-11. doi:10.1007/s13181-011-0165-3.

4. Osorio-Rico L., Santamaria A., Galván-Arzate S. Thallium Toxicity: General Issues, Neurological Symptoms, and Neurotoxic Mechanisms. AdvNeurobiol. 2017; 18:345353. doi: 10.1007/978-3-319-60189-2 17.

5. Yu V., Juhász M., Chiang A., AtanaskovaMesinkovska N. Alopecia and Associated Toxic Agents: A Systematic Review. Skin Appendage Disord. 2018 Oct;4(4):245-260. doi: 10.1159/000485749.

6. Yu H.Y., Chang C., Li F., Wang Q., Chen M., Zhang J. Thallium in flowering cabbage and lettuce: Potential health risks for local residents of the Pearl River Delta, South China. Environ Pollut. 2018 Oct; 241:626-635. doi: 10.1016/j.envpol.2018.05.090.

7. Xiao T., Yang F., Li S., Zheng B., Ning Z. Thallium pollution in China: A geo-environmental perspective. Sci Total Environ. 2012 Apr 1;421-422:51-8. doi: 10.1016/j.scitotenv.2011.04.008

8. Liu Y., Wang Q., Zhuang W., Yuan Y., Yuan Y., Jiao K., Wang M., Chen Q. Calculation of Thallium's toxicity coefficient in the evaluation of potential ecological risk index: A case study. Chemosphere. 2018 Mar;194:562-569. doi: 10.1016/j.chemosphere.2017.12.002.

9. OstapenkoYu.N., Livanov G.A., Shestova G.V., Rutkovsky G.V. Poisoning with thallium compounds (clinic, diagnosis and treatment). Guidelines. M. 2010. 30p.

10. Jiang Y., Xia W., Zhang B., Pan X., Liu W., Jin S., Huo W., Liu H., Peng Y., Sun X., Zhang H., Zhou A., Xu S., Li Y. Predictors of thallium exposure and its relation with preterm birth. Environ Pollut. 2018 Feb;233:971-976. doi: 10.1016/j.envpol.2017.09.080.

11. Aoyama H., Yoshida M., Yamamura Y. Acute poisoning by intentional ingestion of thallous malonate. Hum Toxicol. 1986 Dec;5(6):389-92.

12. Riyaz R., Pandalai S.L., Schwartz M., Kazzi Z.N. A fatal case of thallium toxicity: challenges in management. J Med
Toxicol. 2013 Mar;9(1):75-8. doi: 10.1007/s13181-0120251-1.

13. Galván-Arzate S., Santamaría A. Thallium toxicity. Toxicol Lett. 1998 Sep 30;99(1):1-13.

14. Galván-Arzate S, Santamaría A. Lipid peroxidation (LP) in brain region of developing rats induced by chronic lowlevel thallium administration // Toxicology letters. 1998. - Vol.95, Supplement 1. - P. 55.

15. Hanzel C.E., Verstreaten S.V. Thallium induces peroxide generation by impairing mitochondrial function // Toxicology and Applied Pharmacology. - 2006. Vol. 216. P.485-492.

16. Locatelli C., Petrolini V. Long-lasting polyneuropathy and psychiatric disorders in thallium poisoning. Study of six cases // Toxicology Letters. - 2003. - Vol. 144, Supplement 1. - P. 72 -74.

17. Molina C.P., Versteaten S.V. Thallium (III)-mediated changes in membrane physical properties and lipid oxidation affect cardiolipin-cytochrome $\mathrm{c}$ interaction // BBA Biomembranes. - 2008. Doi:10.1016.

18. Yoshida M., Igeta S., Kavashima R., Akama Y. Changes in adenosine triphosphate (ATP) concentration and its activity in murine tissue after thallium administration // Bull. Environ. Contam. And Toxicol. - 1997. V59. - P. 268- 273.

19. Maya-López M., Mireles-García M.V., Ramírez-Toledo M., Colín-González A.L., Galván-Arzate S., Túnez I., Santamaría A. Thallium-Induced Toxicity in Rat Brain Crude Synaptosomal/Mitochondrial Fractions is Sensitive to Anti-excitatory and Antioxidant Agents. Neurotox Res. 2018 Apr;33(3):634-640. doi: 10.1007/s12640-017-9863-1.

20. Korotkov S.M. Effects of $\mathrm{Tl}(+)$ on ion permeability, membrane potential and respiration of isolated rat liver mitochondria. J BioenergBiomembr. 2009; 41 (3): 277-287.

21. Chou Y.T., Lo K.Y. Thallium(I) treatment induces nucleolar stress to stop protein synthesis and cell growth. Sci Rep. 2019 May 6;9(1):6905. doi: 10.1038/s41598-019-43413-1.

22. Andreeva L.I., Boykova A.A., Petrova V.S., Scherbak S.T., Vorobyov N.V., BelokonitovI.Yu., Sarana A.M., Kuzmich V.G., Ivanov I .A., Margulik B.A., Shabanov P.D. Changes in human blood mitochondria in acute poisoning with thallium salts. Med. Acad. G. - 2001. - 1. - №2 - P. 61-66.

23. Chupovina M.L. Medical and hygienic aspects of thallium neurotoxicity. Hygiene and sanitation - 1999. - №4. P. $38-40$. 


\section{ORIGINAL RESEARCH \\ CLINICAL TOXICOLOGY}

24. Di Candia D., Muccino E., Battistini A., Boracchi M., Gentile G., Zoja R. Thallium toxicity due to adulterer infusion with thallium sulfate in eight members belonging to the same family nucleus: Autopsy findings and ICP-MS analysis (inductively coupled plasma mass spectrometry) in a triple homicide. Leg Med (Tokyo). 2020 Feb;42:101661. doi: 10.1016/j.legalmed.2019.101661.

25. McMilan T.M., Jacobson R.R., Wross M. Neuropsychology of Thallium poisonings. J. of Neurology and Psychiatry. 1997. 63. P.247-250.

26. Osorio-Rico L., Villeda-Hernandez J., Santamaria A., Konigsberg M. The N-Methyl-d-Aspartate Receptor Antagonist MK-801 Prevents Thallium-Induced Behavioral and Biochemical Alterations in the Rat Brain. International J. of Toxicology. 2015. 34(6). P. 505-513 DOI: $10.1177 / 1091581815603936$.

27. Livanov G.A., OstapenkoYu.N., Shestova G.V. et al. Importance of early diagnosis of acute severe poisoning by thallium compounds at the initial stages of intoxication // Toxicol. Bulletin. - 2011. - № 5. - P.1-8.

28. Zavaliy L.B., Petrikov S.S., SimonovaA.Yu. Potskhveria M.M., OstapenkoYu.N. Characterization of neurological disorders in patients with acute thallium poisoning // ConsiliumMedicum. - 2019. - T. 21. - № 2. - P. 24-30.

29. Sharma A.N., Nelson L.S., Hofman R.S. Cerebral spinal fluid (CSF) analysis in fatal thallium poisoning // J. Toxicol. Clin.Toxicol. - 2001. - V. 39. - № 3. - P. 237-238.

30. Senecal P.E., Chalut D. A darket Shade of Prussian blue: The difficult quest for the thallium (Tl) antidote // J. Toxicol. Clin. Toxicol. - 2000. - 38, № 5. - P. 554.

31. Misra U.K., Kalita J. Yadav, Ranjan P. Thallium poisoning: emphasis on early diagnosis and response to haemodialysis // Postgrad Med. J. first published. - 2003. - № 2. - P. 4850. WWW.postgradmed j com.

32. Kuroda H., Mukai Y., Nishiyama S., Takeshita T., Takeshita T., Tateyama M., Takeda A., Aoki M. Tardily accelerated neurologic deterioration in two-step thallium intoxication // J. ClinNeurosci. - 2016. Dec. - 34. - P. 234-236. - DOI: 10.1016/j.jocn.2016.09.003. Epub 2016 Sep. 28.

33. OstapenkoYu.N., Livanov G.A., Shestova G.V., Rutkovsky G.V. and etc. Poisoning with thallium compounds (clinic, diagnosis, treatment) // Method. recommendations. - M. 2010. - $30 \mathrm{p}$.

34. Livanov G.A., Features of early diagnosis and treatment of acute poisoning with thallium compounds // General resuscitation. - 2013. - 3. - P. 35-40.

35. Sun T.W., Xu Q.Y., Zhang X.J., Wu Q., Liu Z.S., Kan Q.C., et al. Management of thallium poisoning in patients with delayed hospital admission // Clin. Toxicol. (Phila). - 2012. - 50 (1). - C. 65-69.

36. Zavaliy L.B., SimonovaA.Yu., Potskhveria M.M., et al. Diagnosis and treatment of thallium poisoning // Toxicological Bulletin. - 2018. - 5 (152). - P. 9-15.

37. Arustamyan O.M., Tkachishin V.S. Poisoning with thallium and its compounds // Medicine of emergency conditions. 2015. - 5 (68). - P. 6-11.

38. Yumoto T., Tsukahara K., Naito H. et al. A successfully treated case of criminal thallium poisoning // J. Clin. Diag. Res. - 2017. - 11 (4). - OD 01-OD 02.

39. Riyaz R., Pandalai S.L., Schwartz M., Kazzi Z.N. A fatal case of thallium toxicity: challenges in management // J. Med. Toxicol. - 2013. - 9 (1). - C. 75-80.
40. Leung K.M. ;Ooi, VEC. (2000). Studies on thallium toxicity, its tissue distribution and histopathological effects in rats // Chemosphere. - 41. - P. 155- 159.

41. Sojakova M., Zigrai M., Karaman A., Plackova S., Klepancova P., Hrusovsky S. Thallium intoxication // Case Report. Neuro Endocrinol. Lett. - 2015. - 36 (4) - P. 311-31.

42. Yang Yongsheng, Faustino P.J. et al. Quantitative determination of thallium binding to ferric hexacyanoferrate: Prussian blue // International J. of Pharmaceutics. - 2008. Vol. 27. - P. 291-295.

43. Yu-Tai Tsai, Chin-Chang Huang et al. Central nervous system effects in acute thallium poisoning // Neuro Noxicjlogy. - 2006. - Vol. 27. - P. 291-295.

44. Guodong Lin, Ph.D., Luo Yuan Ph.D., Lili Bai B.M., Yanging Liu B.M., Yongan Wang Ph.D. and ZewuQiu Ph.D. Successful treatment of a patient with severe thallium poisoning in a coma using Prussian blue and plasma exchange // Medicine (Baltimore). - 2019 Feb. - 98 (8): e 14629. Published online 2019 Feb 22, DOI: 10.1097/MD.0000000000014629. PMCID: PMC 6407929. PMID 30813198.

45. Shabalina L.P., Kirilov V.F., Spiridonova V.S., Polyakova M.M. et al. Diagnostic methods of thallium intoxication and antidotal therapy of tallotoxicosis // Occupational medicine and industrial ecology. - 1996. - No. 10. - P. 25-30.

46. Livanov G.A., Shestova G.V. Sukhodolova G.N., Batotsyrenov B.V. et al. Clinic, diagnosis and treatment of acute severe poisoning with thallium compounds // Ambulance. - 2019 - №3. - P. 9-15.

47. Barroso-Moguee R., Mender-Azmenta M., VillendaHermander I., Rios C., Galvan-Azzate S. Experimental neuromyopathy induced by thallium in rats // J. Appl. Toxicol. - 1996. - 16 No. 5. - P. 389-399.

48. Davis L.E., Standefer J.C., Kornfeld M. et al. Acute thallium poisoning: toxicological and morphological studies of the nervous system // Ann. Neurol. - 1981. - 10. - P. 38-44.

49. Sharma A.N., Nelson L.S., Hoffman R.S. Cerebrospinal fluid analysis in fatal thallium poisoning: evidence for delayed distribution into central nervous system // Am. J. Forensic Med. Pathol. - 2004. - 25. - P. 156-158.

50. Roby D.S., Fein A.M., Bennet R.H. Cardiopulmonary effects of acute Thallium poisoning // Chest. - 1984. 85. - P. 236-240.

51. Kuo H.C., Huang C.C., Tsai Y.T. et al. Acute painful neuropathy in thallium poisoning // Neurology. -2005 . - 65. P. 302-304.

52. Tsai Y.T., Huang C.C., Kuo H.C. et al.Central nervous system effects in acute thallium poisoning // Neurotoxicology. 2006. - 27. - P. 291-295.

53. Lu C.I., Huang C.C., Chang Y.C. et al. Short-term thallium intoxication // Arch. Dermatol. - 2007. - 143 - P. 93-98.

54. Ammendola A., Ammendola E., Argenzio F. et al. Clinical and electrodiagnostic Follow-up of an adolescent poisoned with thallium // Neurol Sci. - 2007. - 28. - P. 205-208.

55. Poddubny N. Poisoning of the century (2012-01-24). URL: https://www.webcitation.org/6DV9upYYYur.

56. Poddubny N. Kill the werewolf. - Kyiv, 2012.

57. Guzhva I., Ilchenko A. Twelve major poisonings of Ukraine https://www.webcitation.org/6DV9wfjiRurl.Segodnya.ua. 2009-07-09.

58. «OtruynaShkola». Documentary series (issue №205 of June 16, 2012, NTV). 


\section{ORIGINAL RESEARCH \\ CLINICAL TOXICOLOGY}

ГОСТРІ ПЕРОРАЛЬНІ ТА ІНГАЛЯЦІЙНІ ОТРУЕННЯ ТАЛІЕМ І ЇХ ВІДДАЛЕНІ НАСЛІДКИ

(Огляд літератури та дані власних досліджень)

Г.М. Балан ${ }^{1}$, А.Г. Богомол ${ }^{2}$, П.Г. Жмінько ${ }^{1}$, Н.М. Бубало ${ }^{3}$ В.О. Бубало ${ }^{1}$, А.Г. Кудрявцева ${ }^{1}$, В.А. Бабич ${ }^{1}$, Т.В. Мимренко

${ }^{1}$ ДП «Науковий центр превентивної токсикології, харчової та хімічної безпеки

імені академіка Л.І. Медведя Міністерства охорони здоров'я України», м. Київ, Україна

${ }^{2}$ Київська міська клінічна лікарня швидкої медичної допомоги, м. Київ, Україна

${ }^{3}$ Державна наукова установа «Науково-практичний центр профілактичної та клінічної медицини» Державного управління справами, м. Київ, Україна

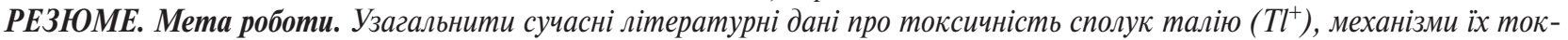
сичної дії та проаналізувати поширеність гострих отруєнь $\mathrm{Tl}^{+}$за останні роки за кордоном і в Україні. Порівняти особливості клінічних проявів і наслідки інтоксикацій $\mathrm{Tl}^{+}$з отриманою дозою і вмістом $\mathrm{Tl}^{+}$в біосередовищах.

Матеріал іметоди. Проведено науковий аналіз даних літератури і власних спостережень щодо поширеності особливостей клінічних проявів і наслідків гострих отруєнь сполуками талію.

Результати. Виявлено зростання поширеності поодиноких і групових випадків гострих отруєнь $\mathrm{Tl}^{+}$в останні роки як за кордоном, так і в Україні. Встановлено, що серед клінічних проявів отруєнь $\mathrm{Tl}^{+}$переважсать неврологічні порушення, шлунково-кишкові та дерматологічні симптоми, вираженість яких переважно залежить від вмісту $\mathrm{Tl}^{+}$у біосередовищі. Висновки: Діагностика гострих отруєнь $T^{+}$у більшості випадків є запізнілою або посмертною. При поєднанні попередніх шлунково-кишкових і дерматологічних розладів з висхідними чутливими і руховими порушеннями іннервації в нижніх і верхніх кінцівках необхідно провести хіміко-токсикологічне визначення $\mathrm{Tl}^{+}$у біосередовищі хворого для виключення інтоксикації.

Ключові слова: талій, механізми токсичної діі, гострі отруєння, діагностика.

\section{ОСТРЫЕ ПЕРОРАЛЬНЫЕ И ИНГАЛЯЦИОННЫЕ ОТРАВЛЕНИЯ ТАЛЛИЕМ И ИХ ОТДАЛЕНННЫЕ ПОСЛЕДСТВИЯ}

(Обзор литературы и данные собственных исследований)

Г.М. Балан ${ }^{1}$, А.Г. Богомол ${ }^{2}$, П.Г. Жминько ${ }^{1}$, Н.Н. Бубало ${ }^{3}$ В.А. Бубало ${ }^{1}$, А.Г. Кудрявцева ${ }^{1}$, В.А. Бабич ${ }^{1}$ Т.В. Мымренко

${ }^{1}$ ГП «Научный центр превентивной токсикологии, пищевой и химической безопасности

имени академика Л.И. Медведя Министерства здравоохранения Украины», г. Киев, Украина

${ }^{2}$ Киевская городская клиническая больница скорой медииинской помощи, г. Киев, Украина

${ }^{3}$ Государственное научное учреждение «Научно-практический центр профилактической

$$
\text { и клинической медицины» Государственного управления делами, г. Киев, Украина }
$$

РЕЗЮМЕ. Цель работы. Обобщить современные литературные данные о токсичности соединений таллия $\left(\mathrm{Tl}^{+}\right)$, механизмах их токсического действия и проанализировать распространенность острых отравлений $\mathrm{Tl}^{+}$за последние годы за рубежом и в Украине. Сопоставить особенности клинических проявлений и исхода интоксикаций $\mathrm{Tl}^{+}$с полученной дозой и содержанием $\mathrm{Tl}^{+}$в биосредах.

Материал и методы. Проведен научный анализ данных литературы и собственных наблюдений о распространенности, особенностях клинических проявлений и исходов острых отравлений соединениями таллия.

Результаты. Вылвлен рост распространенности одиночных и групповых случаев острых отравлений $\mathrm{Tl}^{+}$в последние годы как за рубежком, так и в Украине. Установлено, что среди клинических проявлений отравлений Т( ${ }^{+}$преобладают неврологические нарушения, желудочно-кишечные и дерматологические симптомы, выраженность которых в большинстве случаев зависит от содержания $\mathrm{Tl}^{+}$в биосредах, преимущественно в моче и ногтях.

Выводы. Диагностика острых отравлений $\mathrm{Tl}^{+}$в большинстве случаев оказывается запоздалой или посмертной. При сочетании предшествующих желудочно-кишечных и дерматологических расстройств с болезненными парестезиями и восходящими чувствительными и двигательными нарушениями иннерващии в нижних и верхних конечностях необходимо провести химико-аналитическое определение $T l$ в биосредах больного для исключения или подтверждения интоксикации.

Ключевые слова: таллий, механизмы токсического действия, острые отравления, диагностика. 